\title{
Corporate Ethical Identity as a Determinant of Firm Performance: A Test of the Mediating Role of Stakeholder Satisfaction
}

\author{
E \\ Pascual Berrone \\ Jordi Surroca \\ Josep A. Tribó
}

\begin{abstract}
In this article, we empirically assess the impact of corporate ethical identity (CEI) on a firm's financial performance. Drawing on formulations of normative and instrumental stakeholder theory, we argue that firms with a strong ethical identity achieve a greater degree of stakeholder satisfaction (SS), which, in turn, positively influences a firm's financial performance. We analyze two dimensions of the CEI of firms: corporate revealed ethics and corporate applied ethics. Our results indicate that revealed ethics has informational worth and enhances shareholder value, whereas applied ethics has a positive impact through the improvement of SS. However, revealed ethics by itself (i.e. decoupled from ethical initiatives) is not sufficient to boost economic performance.
\end{abstract}

Pascual Berrone is a PhD candidate of the Business Administration and Quantitative Methods Ph.D. program at the Universidad Carlos III de Madrid. His current research interests focus on business ethics, stakeholder theory, and various aspects of the interface between corporate governance mechanisms and corporate social responsibility. His interests also include ethical, environmental and social issues and their impact on firms' overall performance.

Dr. Jordi Surroca is an Assistant Professor of Management at the Department of Business Administration at the Universidad Carlos III de Madrid. He holds a PhD in Business Administration and a Licentiate Degree in Business and Economics from Universitat Autònoma de Barcelona. His research interests center on stakeholder management, firm strategy, innovation, and corporate governance.

Dr. Josep A. Tribo is Associate Professor of Finance in the Department of Business Administration at the Universidad Carlos III de Madrid. He has a PhD in Economic Analysis from the Universitat Autònoma de Barcelona and a Licenciate Degree in Theoretical Physics by Universitat de Barcelona. His research interests are Corporate Finance and the financing of RED. His work has been published in journals such as Applied Economics, International Journal of Production Economics.
KEY WORDS: business ethics, corporate ethical identity, financial performance, stakeholder satisfaction, stakeholder theory

ABBREVIATIONS: CEI: corporate ethical identity; CRE: corporate revealed ethics; CAE: corporate applied ethics; SiRi: sustainable investment research international; KLD: Kinder, Lyndenburg, Domini Research and Analytics Inc.; SS: stakeholder satisfaction; CFP: corporate financial performance; MVA: market value added; ROA: return on assets; R\&D: research and development

\section{Introduction}

During the last decades, the ethical behaviour of firms and the potential effects of malfeasance on society have attracted the interest of researchers and the business press alike. Recently, business ethics has generated renewed attention due to notorious cor porate scandals like those of Enron, Worldcom, Arthur Andersen, Tyco International, and Adelphia. Additionally, the growing importance of govern mental regulations, the amplified scrutiny of the media, and increased pressure from various stake holders have placed the business ethics challenge on the strategic agenda of virtually all firms (Ponemon and Michaelson, 2000; Stevens et al., 2005; Weaver et al., 1999). In the academic arena, the proliferation of specialized journals like Journal of Business Ethics and Business Ethics Quarterly are testaments to growing interest in the subject.

There is still a number of unresolved academic issues in the area of business ethics and social responsibility of the firm, however (Donaldson, 2003; Harrison and Freeman, 1999; Walsh et al., 2003). Specifically, knowledge about existing linkages 
between a firm's ethical stance and its performance remains limited at best. There are theoretical and empirical reasons for this situation. From a theoretical point of view, there is controversy over the effect of business ethics and good corporate behaviour on a firm's financial performance. Some authors (Hosmer, 1994; Jones, 1995) argue that good ethics is good business because it generates positive externalities like trust and commitment to stakeholders, which in turn assures long term performance. Others remain skep tical (Friedman, 1970; Jensen, 2001; Schwab, 1996). The skeptics argue that ethical initiatives are invest ments without pay offs and therefore against the shareholder's best interest. Unfortunately there is limited empirical work that has explicitly addressed these corporate ethical issues and the existing research has shown mixed results (e.g. Berman et al., 1999; Hillman and Keim, 2001). Thus the question remains: Is ethical behaviour a good predictor of business performance (Gibson, 2000)?

An interesting avenue for exploring the relation ship between ethics and performance is through the perspective of corporate identity - the set of inter dependent characteristics of the organization that give it distinctiveness: organizational philosophy, values, history, strategy, business scope, and com munication, for instance (Balmer, 1998, 2001; van Riel and Balmer, 1997). Since corporate identity is recognized as a source of competitive advantage (Balmer and Gray, 2000), we suggest that a firm's ethical stance (i.e., its ethical values, behaviours, and communications on ethical commitments) can be seen as a component of the firm's corporate identity that may enhance corporate performance.

Despite the significance that corporate identity research has recently engendered (Balmer, 1998, 2001), previous research has largely ignored the ethical dimension of corporate identity and its rela tionship to a firm's performance. This study aims to fills this gap in several ways. First, we define the ethical component of the corporate identity con struct with a concept that we call corporate ethical identity (CEI). Relying on the notion of corporate identity, we define CEI as "the set of behaviours, communications, and stances that are representative of an organization's ethical attitudes and beliefs". This narrowly defined concept encompasses two aspects: corporate revealed ethics (CRE), which com prises the communication of a firm's ethical attitudes and beliefs, and corporate applied ethics (CAE), which comprises the firm's behaviours - actions and poli cies that can be considered as ethical.

A second way in which we aim to contribute to this literature is by drawing on stakeholder theory to propose a theoretical scheme whereby the gap between performance and ethics - specifically CEI is bridged by stakeholder satisfaction (SS). Stake holders play a key role in the formation of society's ethical demands and CEI emerges as a standard by which stakeholders compare the firm's ethical behaviours to their expectations. Thus, a strong CEI implies congruence with the ethical demands of the firm's stakeholders, resulting in higher levels of sat isfaction. In turn, satisfied stakeholders are expected to be more willing to provide their services and resources to the firm, thereby enhancing performance.

A third way in which we plan to fill the gap between corporate identity and a firm's performance is to empirically test our theoretical contention. Our results indicate that firms with a strong CEI achieve a greater degree of SS, and this, in turn, positively affects a firm's financial performance. Also, we have found that CAE and CRE have differential effects. Whereas applied ethics has a positive impact on performance through improved SS, revealed ethics has informational worth and enhances shareholder value directly. However, revealed ethics by itself (i.e. decoupled from ethical initiatives) is not sufficient to boost economic performance.

The remainder of this article is structured as fol lows. First, we define CEI and its dimensions. Next, we present relevant literature relating to the objec tives of this work and our theoretical formulation. We propose a set of hypotheses grounded in the logic of stakeholder theory, through which we analyze the relationship between CEI and the financial performance of firms. Next, we test our hypotheses on a sample of 398 firms from 26 countries. The article concludes with a discussion of the theoretical and practical significance of the study.

\section{Theoretical framework and hypotheses}

Perhaps because of the rapid growth of identity studies, the concept of corporate identity has not been homogenously defined. The lack of consensus on a precise definition of corporate identity has led to 
confusion with the usage of the term, which is often wrongly used interchangeably with related concepts like corporate reputation, corporate personality, and corporate image (see Balmer and Gray, 2003; Hatch and Schultz, 1997; and especially Balmer, 2001, for a clarifying discussion on this issue). Traditionally, the notion of corporate identity has been associated with graphics design, visual identification, and marketing communication. More recently, however, the defi nition of corporate identity has gradually broadened (Markwick and Fill, 1997; van Riel and Balmer, 1997). Thus corporate identity can be defined as the "the reality and uniqueness of an organization which is integrally related to its external and internal image and reputation through corporate communication" (Balmer and Gray, 2000; Gray and Balmer, 1998). Corporate identity deals with the essence of the firm and its unique characteristics: its philosophy, values, history, strategy, business scope, and communication (Balmer, 1998, 2001; Balmer and Gray, 2003; van Riel and Balmer, 1997).

Corporate identity is receiving increasing atten tion from practitioners and academics alike, because it is believed to have a positive influence on cor porate reputation (Fombrun, 1996), which, in turn, spawns superior financial performance (Deephouse, 2000; Fombrun and Shanley, 1990; Roberts and Dowling, 2002). Corporate identity is also recog nized as a strategic resource and a valuable tool for addressing the needs of the firm's stakeholders (van Riel, 1995). Indeed, corporate identity and such related concepts as corporate communication and organizational identity are the result of permanent interactions between the firm and its stakeholders (Balmer and Gray, 2000; Hatch and Schultz, 1997; Scott and Lane, 2000; Stuart, 2002; van Riel and Balmer, 1997). Stakeholders have interests and demands, and the way in which a firm manages these claims contributes to the shaping of its corporate identity, insofar as its values, actions, and stance differentiate it from other organizations. ${ }^{1}$

\section{CEI: definition and components}

One neglected area of research is the ethical dimension of corporate identity. Yet, the firm's ethical behaviours and stance are also part of its reality and uniqueness. In this paper, we offer a definition of the ethical dimension of corporate identity that we call CEI. Bearing in mind the aforementioned defi nition of corporate identity, we approach the CEI concept as "the set of behaviours, communications, and stances that are representative of an organization's ethical attitudes and beliefs". It contributes to the organization's reality and uniqueness and reflects the extent to which a firm can be considered ethical. Thus, CEI refers to a firm's ethical goals, values, practices, communications, and actions, and provides a reference for stakeholders to compare their ethical claims with the ethical stance of the corporation.

In the same way that corporate identity is the result of continuous interaction between the firm and its stakeholders, CEI is influenced by the interaction between a firm and its stakeholders' ethical claims (Fombrun and Foss, 2004; Fritz et al., 1999; Logsdon and Yuthas, 1997). The ethical stance of a firm is based on the expectations of society - the legitimate claims made by the constituencies with which the firm interacts (Logsdon and Yuthas, 1997; Mitchell et al., 1997; Wood, 1991). In the words of Ferrell et al. (2000), if "a specific required behaviour is right or wrong, ethical or unethical, is often determined by stakeholders, such as investors, customers, interest groups, employees, the legal system, and the com munity" (p. 6). Recent empirical studies support the previous argument. For instance, Weaver et al. (1999) showed that the orientation of corporate ethics programs reflected both external influences (e.g. institutional environment) and internal pressures (e.g. top management). Such ethical endeavours as ethics programs merge the organization's decisions and the ethical claims of society (Weaver et al., 1999). In a similar vein, Stevens et al. (2005) found evidence that financial executives are more likely to integrate their firm's ethical code into their strategic decisions if they perceive pressure from market stakeholders. Other factors such as the idiosyncratic position of a firm's executives toward corporate ethics can influ ence the ethical stance of an organization (Weaver et al., 1999). Also, these studies indicate that ethical decisions and actions are at least partially the result of the interaction between the firm and its stakeholders. As we argue later in the paper, when there is congruence between the firm's ethical actions and societal ethical claims, stakeholders are expected to be satisfied. Thus SS is defined as the extent to which the stakeholders' claims are met by the firm's actions. 
Because corporate identity is a multidimensional concept (Melewar and Jenkins, 2002), various dimensions can be identified. Previous literature seems to show consensus on two main factors communication and behaviour - that define cor porate identity and the way it is demonstrated to internal and external audiences (van Rekom, 1997; van Riel, 1995; van Riel and Balmer, 1997). Communications refer to the explicit revelation of such aspects of identity as history and values. Cor porate communication plays a pivotal role in the process through which stakeholders perceive that the company's identity and reputation is formed (Balmer and Gray, 2000; van Rekom, 1997). Behaviours are related to those activities and actions that charac terize corporate identity. Likewise, we identify two dimensions that define the CEI: (1) what we call CRE, which deals with the communication of the firm's ethical identity to its constituencies and rele vant audiences and (2) what we term CAE, which deals with all actions and policies that can be con sidered ethical, thereby exceeding the simple com munication of ethical values. It is important to distinguish these ethical actions from other initiatives that are related to the good management of stake holders (Fisher, 2004). Whereas the latter deals with everyday activities like employee training programs or profit sharing schemes, ethical actions refer to processes, activities, and events conducted on an ethical basis that go beyond a firm's daily functions. For instance, the adoption of ethical codes as a self commitment device, initiatives like HIV/AIDS programs, or divesting from a country to avoid corruption problems are examples of the application of ethics (Margolis and Walsh, 2003).

The distinction between CRE and CAE provides us with a better understanding of the relationships among CEI, SS, and corporate financial performance (CFP). In the following sections, we focus on these relationships.

\section{Stakeholder theory}

Because stakeholders are engaged in constructing the ethical identity of firms, a stakeholder approach appears to be the appropriate framework to connect ethics with performance. Moreover, management scholars studying ethical and social issues have generated an extensive body of research (Garriga and Melé, 2004; Margolis and Walsh, 2003) drawn primarily on stakeholder theory (Freeman, 1984).

Stakeholder theory has deep roots in the notion of corporate social responsibility (Carroll, 1979; Clarkson, 1995; Wartick and Cochran, 1985; Wood, 1991) and in Freeman's (1984) seminal book, Strategic Management: A Stakeholder Approach. Free man's main thesis is that the firm is responsible for managing and coordinating the constellation of competitive and cooperative interests of various constituencies or stakeholders. Thus, firms have multiple goals in addition to the singular end of maximizing shareholder's value, as proposed by tra ditional economic theory (Friedman, 1970).

In applying stakeholder theory, we can distinguish two almost entirely separate methodological approaches: (1) the theoretically-based normative stakeholder approach, which emphasizes the ethical and moral standards as the only acceptable mode for corporate behaviour, independent of the repercus sions of these behaviours on the firm's performance and (2) the instrumental stakeholder approach, which focuses primarily on stakeholder orientation as a means of achieving corporate success. Research employing the latter perspective is more empirically based (Berman et al., 1999; Donaldson and Preston, 1995; Jones and Wicks, 1999).

Recently, however, some scholars have attempted to integrate the two approaches (Gibson, 2000; Jones, 1995; Jones and Wicks, 1999). The underly ing rationale of their studies is that ethical behaviours (a normative orientation) can result in a significant competitive advantage (an instrumental orientation). Ethical principles and behaviours foster trusting and cooperative relationships with stakeholders, which, in turn, lead to a reduction in opportunism and contracting costs. In the end, there is an improve ment in the firm's competitive advantage over those firms that do not rely on ethical principles. Although some scholars have expressed skepticism over this integrated perspective (Donaldson, 1999; Freeman, 1999; Schwab, 1996; Treviño and Weaver, 1999), we believe that it provides a key avenue for research into the ethical and social issues of firms.

Following this integrated line of research, we borrow from the normative approach to examine the relevance of business ethics as the driving force for SS and from the instrumental approach to assess 


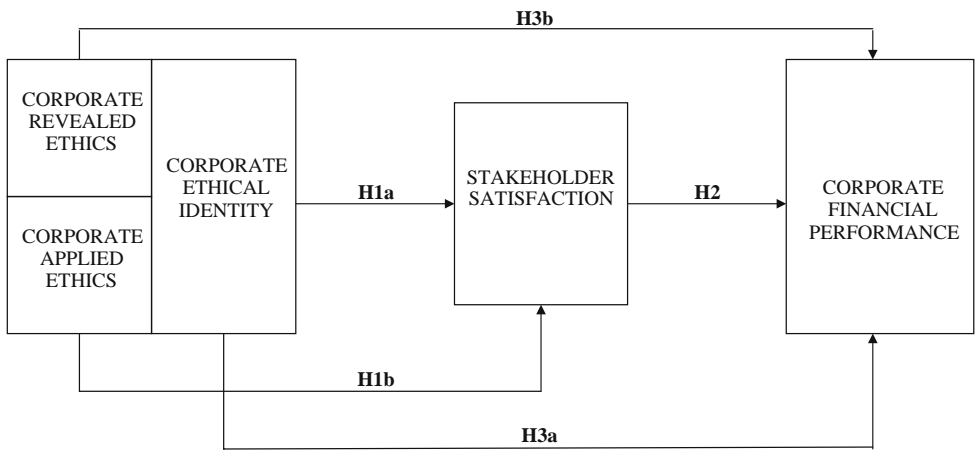

Normative approach

Instrumental approach

Figure 1. Corporate ethical identity and its effects on stakeholder satisfaction and financial performance.

the link between SS and better financial perfor mance. Figure 1 illustrates our theoretical model and presents the central arguments, concepts, and rela tionships of this study.

\section{SS through CEI: a normative approach}

The normative approach is characterized by the incorporation of ethical and moral principles into the firm's decision making - in particular, into decisions relating to the way in which a firm manages its stakeholders (Donaldson and Dunfee, 1994; Evan and Freeman, 1983; Philips, 1997; Wicks et al., 1994). The normative approach is characterized by two main positions: (1) stakeholders have legitimate interests in corporate activities independent of the corporation's instrumental interests in them and (2) each stakeholder is of intrinsic worth (Donaldson and Preston, 1995). Thus, the normative core of the stakeholder approach prescribes that a firm should incorporate ethical standards in order to achieve SS. Under the normative approach, SS should be the final goal of the firm because of the intrinsic worth of stakeholder interests. These interests are based on ethical and moral principles and are not necessarily related to their instrumental worth to the corpora tion (Berman et al., 1999; Donaldson and Preston, 1995; Evan and Freeman, 1983).

Stakeholders have a set of expectations relating to an organization's ethical activities and various groups, such as managers, employees (Das, 2005; Grojean et al., 2004), government (Rockness and Rockness, 2005), consumers (Rawwas et al., 2005), and other constituencies (Phillips and Reichart, 2000) reveal these expectations. As previously argued, CEI pro vides a reference or standard for stakeholders to use in evaluating a firm's actions (behaviours and commu nications). When there is congruence between stakeholder expectations and CEI, we predict a greater degree of SS. Since stakeholders expect a firm to fulfil its ethical responsibilities and its philan thropic duties (Ferrell et al., 2000), ethical manifes tations stimulate the formation of trust and commitment between the stakeholders and the firm, resulting in stronger relationships and greater satis faction (Fritz et al., 1999; Hosmer, 1994; Strong et al., 2001). Hence, our first hypothesis is:

Hypothesis 1a: The CEI of the firm has a positive influence on stakeholder satisfaction.

However, we expect that the two components of CEI will have differential effects on SS: that CAE will have a greater impact than CRE. Whereas CRE signals the ethical stance of the firm and acts as a declaration of purpose for the firm's future actions, CAE involves specific concrete activities to serve the needs of stakeholders who demand ethical behaviour from the firm. Stakeholders evaluate how well companies perform according to their ethical expectations and standards and exhibit a certain degree of fulfilment only when they experience tangible results from such 
ethical corporate behaviour (Logsdon and Yuthas, 1997). This suggests that the manifestation of ethical values decoupled from ethical actions may be not valued by stakeholders. Therefore, we expect that the revelation of a firm's ethical beliefs is less effective in boosting satisfaction than are the tangible ethical initiatives that align with stakeholder demands. These arguments are captured in:

Hypothesis 1b: CAE has a stronger influence on stakeholder satisfaction than does CRE.

Financial performance through SS: an instrumental approach

The other main approach of stakeholder theory is the instrumental approach. It indicates that a stakeholder orientation gives the firm a source of competitive advantage which, in turn, will result in better financial performance. A key assumption of this approach is that the firm's ultimate goal is market success and that satisfying stakeholder claims helps to achieve this goal (Donaldson and Preston, 1995; Freeman, 1984). This ultimate objective may not be related to the wellbeing of stakeholders in general, but it may be in the interest of shareholders. Thus, stakeholder management has a strategic value with a "means to an end" perspective (Berman et al., 1999), which is opposed to the intrinsic value of the normative approach.

The instrumental approach advocates the formu lation and implementation of processes that satisfy stakeholders because they control key resources (Pfeffer and Salancik, 1978) and suggests that SS, in turn, will ensure the long term survival and success of the firm (Freeman, 1984; Freeman and McVea, 2001; Hillman and Keim, 2001; Post et al., 2002). Accordingly, stakeholders that own resources rele vant to the firm's success will be more willing to offer their resources to the extent that their different claims and needs are fulfilled (Strong et al., 2001). Therefore, we expect that SS leads to a higher commitment, to greater effort, and, ultimately, to superior performance (Hosmer, 1994; Stevens et al., 2005), as articulated in:

Hypothesis 2: Stakeholder satisfaction has a positive influence on the firm's financial performance.
Financial performance through CEI: the mediating role of $S S$

Whether or not business ethics has a positive influ ence on financial performance is an open research question. Some authors (Friedman, 1970; Jensen, 2001; Schwab, 1996) assert that the only social function of the firm is to maximize shareholder value while complying with the rules of the market. These scholars argue that ethical investments are in conflict with the primary profit oriented strategies of the company, and that if investors cared enough about ethical behaviour to punish it by divesting, firms would have a market based incentive to behave ethically. The necessity of regulations such as the US Sarbanes Oxley legislation (Rockness and Rockness, 2005), which levies severe penalties for unethical behaviour, suggests that such market incentives are highly uncertain.

In contrast, other authors have argued that proactive ethical initiatives have a positive impact on financial performance because ethical behav iours result in the creation of intangible assets, which are vital to long term business success (Jones, 1995; Jones and Wicks, 1999). Intangibles like good reputation, trust, and commitment are generated through a strong ethical stance (Fomb run et al., 2000; Hosmer, 1994). We agree with this latter perspective. By behaving ethically, a company generates intangible gains that improve its ability to attract resources, enhance perfor mance, and build competitive advantages while satisfying its stakeholders' needs (Fombrun et al., 2000). As discussed with respect to Hypothesis 1a, we propose that CEI has a positive effect on SS because stakeholders expect the firm to fulfil their ethical demands. To the extent that the firm at tends the stakeholders' ethical claims, their satis faction levels increase and they are more willing to provide their resources and effort which, in turn, produces enhanced performance (Hypothesis 2). Therefore, we suggest that the relationship between business ethics and financial performance is not straightforward, but is mediated by the level of SS. That is, we expect an indirect effect between the CEI of the firm and its financial performance. 
Hypothesis 3a: Stakeholders satisfaction mediates the relationship between CEI and the firm's financial performance.

However, when we break CEI into its two dimensions, we expect distinguishable effects on financial performance.

Traditional capital market studies have largely acknowledged the role of information disclosure on the performance of firms. Asymmetries of information and incentive problems obstruct the efficient allocation of resources in a capital market economy and disclosure plays a key role in miti gating these problems (Healy and Palepu, 2001). Prior research has extensively examined the level of disclosure of social activities and its effect, particularly when analyzing the relationship between corporate social performance and CFP (see Margolis and Walsh, 2003; Orlitzky et al., 2003; Walsh et al., 2003 for recent reviews). In addition, environmental accounting scholars have shed some light on the subject by analyzing the impact of voluntary environmental disclosure on firm per formance (Cragg, 2002; Lorraine et al., 2004). As a whole, these two lines of research offer sup porting evidence for a positive relationship between social disclosure and financial performance.

Similarly, we expect CRE to have a positive impact on the financial performance of a firm. CRE can have beneficial value to for several reasons. (1) It attends to the investors' need for ethical and social information which, in turn, helps to achieve better long term investment decisions (Hummels and Timme, 2004; Sethi, 2005). (2) It provides a clear signal about the stance and beliefs of the firm, reducing uncertainty about future actions and long term risks (Sethi, 2005), which can stimulate trust and commitment between shareholders and top management and reduce opportunistic behaviours and transactional costs (Hosmer, 1994; Jones, 1995). (3) It may be a valuable tool for creating such intangible assets as good corporate image and en hanced reputation, which can be sources of com petitive advantage (Fombrun, 1996; Fombrun and Foss, 2004; Hillman and Keim, 2001). (4) Investors may interpret an ethical statement as a positive signal regarding the firm's resources, because only com panies with sufficient resources can embark on eth ical enterprises (cf. Orlitzky et al., 2003; Waddock and Graves, 1997). In short, CRE has an important informational value, and we expect that investors incorporate ethical information into their assessment of a firm's value.

Even though CRE is expected to increase share holder value because of these arguments, CAE is an initiative oriented to specific stakeholder needs and does not necessarily represent investments subject to return evaluation (Fombrun et al., 2000). Following the example presented earlier in this article, divesting from a country to avoid corruption problems can be considered an ethical initiative, but it does not nec essarily represent an optimal decision from the per spective of maximizing value. Similarly, investing in HIV/AIDS programs can be of fundamental impor tance to people stricken with the disease, but is not expected to have a direct impact on the financial performance of the firm. Hillman and Keim (2001) have presented empirical evidence to suggest that participation in social initiatives that are not related to primary stakeholders hinders shareholder value. Al though these initiatives may have potential reputa tional benefit and a positive impact on SS (Hypothesis 1b), they are costly in terms of organi zational resources and create dubious financial pay offs (Hillman and Keim, 2001; Fombrun et al., 2000).

Therefore, we expect, on the one hand, that the informational value of CRE has a positive impact on the financial performance of a firm, even after controlling for its effects on SS. On the other hand, we expect no further positive impact of CAE beyond the positive effect on SS. This implies that the effect of CAE on performance is fully mediated by SS. These two ideas are captured in our final hypothesis.

Hypothesis 3b: Corporate revealed ethics has a positive influence on financial performance, even after controlling for stakeholder satisfaction; whereas CAE has no further influence.

\section{Methods}

Sample and data

We created our data sample from the $2002 \mathrm{SiRi}$ Pro ${ }^{\mathrm{TM}}$ database compiled by the company Sustain able Investment Research International (SiRi) - the 
world's largest company specializing in the analysis of socially responsible investment. SiRi comprises eleven independent research institutions, such as the US firm of Kinder, Lyndenburg, Domini Research and Analytics Inc. (KLD) or the UK firm of Pensions and Investment Research Consultants Ltd. The SiRi reports rely on each company's reporting proce dures, policies and guidelines, management systems, and key data. This information is extracted primarily from ongoing contact with management represen tatives, but also from financial accounts, company documentation, international databases, media reports, and interviews with key stakeholders. Each firm's profile contains over 350 data points that cover all major stakeholder issues, including com munity involvement, environmental impact, cus tomer policies, employment relations, human rights, activities in controversial areas (e.g. alcohol), sup plier relations, and corporate governance. We sup plemented the information on social and ethical issues with financial data extracted from the OSIRIS database for the years 2000-2003 - a comprehensive database of listed and large unlisted companies around the world, compiled by Bureau Van Dijk. It contains balance sheets, income statements, cash flow statement, and stock data. Given the differences in accounting practices among the different coun tries included in the database, it is important to note that OSIRIS's information is standardized.

We excluded from our sample financial firms and those that do not provide complete information on financial data. The final sample comprised 398 companies belonging to 26 countries. ${ }^{2}$ Our data only allow a cross sectional analysis because our information is limited to one year from the SiRi Pro $^{\mathrm{TM}}$. This limitation is not critical in our analysis, given the inertia associated with a firm's ethical policies (Agle et al., 1999).

\section{Measures}

\section{Corporate ethical identity}

We operationalized this variable through the sum of its two basic ethical components: CRE and CAE.

\section{Corporate revealed ethics}

A mission statement is seen as the starting point for revealing a corporate identity program, as it is an effective vehicle by which a firm's essential values are communicated to its stakeholders (Leuthesser and Kohli, 1997). Issues of business ethics are likely to be explicit in mission statements, and mission state ments are included in annual reports or in other corporate statements. To measure the CRE variable, we used the SiRi Pro ${ }^{\mathrm{TM}}$ database, which contains business ethics report. In the first part of this report, SiRi analysts study the various corporate statements and determine if the company discloses relevant information related to its ethical business behaviour. As a result, SiRi builds a dummy variable in which the company scores " 1 " on this item if it discloses information on business ethics in the corporate statements and " 0 " if it does not. In our empirical application, we used this item provided by SiRi.

\section{Corporate applied ethics}

We measure CAE using another dummy variable. In this case, the SiRi analysts assess the organization's business ethics initiatives, policies, and procedures. Specifically, the company statements are inspected in order to identify any specific ethical procedures (and the scope of any such procedures) compliant with the standards of business ethics. The company is labeled "ethical" (a score of " 1 ") if it conducts all of the following actions: withdraws from a market to avoid corruption problems; has an explicit, readily available employee ethics policy; has a contact per son in case of irregularities; guarantees that the reporting agent remains anonymous; and uses sanctions for unethical behaviours. If the company does not employ these business ethics procedures, it receives a score of " 0 ".

\section{Stakeholder satisfaction}

SS is viewed as a multidimensional construct (Carroll, 1979) that captures a wide range of items at least one for each relevant stakeholder (Waddock and Graves, 1997). In the past few years, the KLD Social Index has been used extensively in empirical research on stakeholder theory and has been found to be one of the best measures of SS available to date (Hillman and Keim, 2001). This index provides a measure of the overall wellbeing of a firm's multiple stakeholders. $^{3}$

In this study, we use the score provided by the SiRi Pro ${ }^{\mathrm{TM}}$. This score aggregates the degree to which the company satisfies stakeholders' interests and rates SS from 0 (worst) to 10 (best). Taking into 
account the score received by each stakeholder group or area - community, corporate governance, customers, employees, environment, and vendors and contractors - SiRi builds an aggregate score, which we use as our final measure of stakeholder satisfaction. $^{4}$

\section{Corporate financial performance}

A great deal of debate surrounds the use of financial measures to assess performance. We use a market based measure: market value added (MVA). In addition, for the sake of robustness, we provide results using an accounting based measure, return on assets (ROA). MVA is calculated as the equity market valuation of the company minus the capital invested in the company, and can be interpreted as the stock market's estimation of net present value (Hillman and Keim, 2001). ROA is defined as the ratio of profits before interest and taxes to total assets. Accounting measures of financial perfor mance are inadequate for conducting large cross sectional comparisons across industries, because the results may mask differences in financial perfor mance based on the specific context of an industry (Griffin and Mahon, 1997). Thus, we use a fre quently applied method for controlling industry effects (e.g. Agle et al., 1999), a measure arrived at by subtracting the average ROA of the industry from each firm's ROA.

Although many different measures of financial performance could have been used, we emphasize market based measures because they better capture the expected future impact of ethics on performance. Specifically, the informational value of CRE can only be measured through variables that discount the expected future intangible investment derived from a firm's revealed ethical behaviour. Such variables are forward looking measures (market performance variables) rather than backward looking measures (accounting performance variables). On this point, several authors have acknowledged the deficiencies of accounting measures in capturing intangible relationships and the benefits provided by market based measures (Hillman and Keim, 2001; Orlitzky et al., 2003).

\section{Control variables}

We control for R\&D investment, marketing con troversies, firm size, industry, risk, and country fol lowing the lead of previous researchers (McWilliams and Siegel, 2000; Waddock and Graves, 1997). We operationalized these variables as follows:

$R \& D$ investment is defined as the ratio of $\mathrm{R} \& \mathrm{D}$ expenses to total assets in a $\log$ scale. McWilliams and Siegel (2000) showed that R\&D is positively correlated with stakeholder performance and financial performance. As they point out, a major determinant of the financial performance of firms is their spending on R\&D, because it leads to product and process innovation and enhances firm produc tivity. At the same time, the correlation between $\mathrm{R} \& \mathrm{D}$ and SS is explained by the fact that many aspects that create utility for a firm's stakeholders are generated through product or process innovations. Thus, in order to isolate the real impact of a firm's SS on financial performance, we need to control for investment in R\&D. Otherwise, we would provide upward biased estimators of the SS variable.

Marketing controversies is intended to capture the marketing practices of firms - a variable that has been shown to be an important determinant of financial performance and SS. Consequently, an appropriate econometric model must include a proxy variable for marketing practices, and we use SiRi's dummy variable "existence of controversies over marketing practices". This variable takes a va lue of " 1 " if the firm has controversies over product quality and safety or if the firm benefits from market power over its clients and a value of " 0 " otherwise. Irresponsible marketing practices - i.e. controversies on product quality and safety or the abuse of market power - is expected to decrease SS (Moskowitz, 1975). Therefore, we expect marketing controver sies to be negatively related to SS. Consistent with our theoretical model, we also expect that marketing controversies will have a negative effect on financial performance. However, there may be an opposite effect, given that a high level of controversy could also indicate the market power of the firm. A firm with strong market power (e.g., a monopolist firm) can take advantage of its power financially and pass the costs of advertising to customers (Tannous, 1997). This practice will result in bigger advertising budgets, which are expected to have a positive impact on performance (McWilliams and Siegel, 2000) but result in high levels of controversy (e.g. unhappy customers because of excessive pricing). As 
a consequence, the influence of marketing contro versies on CFP is unclear because we do not know which of these two effects will prevail.

Size is defined in terms of a firm's total sales on a $\log$ scale. The size of a firm is a standard factor in explaining the ethical basis of CFP and SS. A firm's commitment to a particular ethical behaviour and the instruments it has available to implement this com mitment is expected to be related to the size of a firm.

Risk is measured by a firm's beta (Hillman and Keim, 2001) as reported by OSIRIS. This variable is recognized as a pivotal determinant in any esti mation of financial performance. Moreover, we allow this variable to affect SS. Stakeholder well being is expected to be related to the possibility of financial distress (Roberts, 1992). A firm with a strong orientation towards its stakeholders may be viewed as being better managed and therefore as being less risky and vice versa (a firm with lower risk is more likely to be committed to satisfying its stakeholders).

We control for industry and country, as there are 13 sectors and 26 countries in our sample. Industry effects are captured by 4 digit SIC dummy variables (DummyS). To control for country influences, we use a set of 25 dummy variables (DummyC).

Finally, in order to prevent potential endoge neity problems between measures and consistent with previous studies like that of McWilliams and Siegel (2000), we used the mean of all our vari ables. The underlying idea is that by averaging variables, it is possible to find more robust coeffi cients in the estimations because the error terms are less highly correlated with the average independent variables.

\section{Data analysis and model specification}

A test for identifying outliers in multivariate data was performed. The method developed by Hadi (1992, 1993) indicated that we have significant outliers in our data. It is well known that ordinary least squares are sensitive to outliers (Berk, 1990). In this case, robust regression may be the only reasonable statis tical recourse (Hamilton, 1992) because it limits the influence of outlying observations and allows for more robust inferences. 5

In our empirical application, we rely on two basic specifications, one explaining SS and one explaining
CFP. The main independent variable in both cases is CEI, which is also separated into its component parts, CRE and CAE. Following previous research (Waddock and Graves, 1997), we consider the same set of control variables in explaining CFP and SS. In order to explain a firm's SS and test Hypothesis 1a, we consider the following specification:

$$
\begin{array}{r}
\mathrm{SS}_{i}=\alpha_{0}+\alpha_{1} \mathrm{CEI}_{i}+\alpha_{2}{\mathrm{R} \& \mathrm{D}_{i}} \\
+\alpha_{3} \text { MARKETING_CONTROVERSIES }_{i} \\
+\alpha_{4} \mathrm{SIZE}_{i}+\alpha_{5} \text { RISK }_{i}+\sum_{K=1}^{12} \alpha_{5+K} \text { DummyS }^{25} \alpha_{17+K} \text { DummyC }^{25} \sum_{K=1}
\end{array}
$$

In analyzing the possible differential effect of CRE and CAE on SS, as stated in Hypothesis 1b, we conducted two further estimations of specification (1) by breaking the variable CEI into its two basic components: CRE and CAE.

The second equation is aimed at explaining CFP and, as mentioned, we contemplate the same basic control variables as in specification (1). Hence, the basic specification is:

$$
\begin{aligned}
\mathrm{CFP}_{i} & =\beta_{0}+\beta_{1} \mathrm{SS}_{i}+\beta_{2} \mathrm{CEI}_{i}+\beta_{3} \mathrm{R}_{2} \mathrm{D}_{i} \\
& +\beta_{4} \text { MARKETING_CONTROVERSIES }_{i} \\
& +\beta_{5} \text { Size }_{i}+\beta_{6} \text { Risk }_{i}+\sum_{K=1}^{12} \beta_{6+K} \text { Dummy } S \\
& +\sum_{K=1}^{25} \beta_{18+K} \text { DummyC }
\end{aligned}
$$

From this specification, it is possible to test Hypotheses 2, 3a, and 3b. More specifically, to test Hypothesis 2, we exclude the CEI variable from specification (2) in order to study the existence of a direct effect of SS on CFP. This hypothesis is con firmed when $\beta_{1}$ is positive. To test the mediating role of SS (Hypotheses 3a and 3b), we follow the meth odology described in Baron and Kenny (1986). In the case of Hypothesis 3a, the methodology consists of comparing two specifications: one that excludes the SS variable and one that incorporates all the variables. This hypothesis is confirmed when two conditions are met: (1) $\beta_{2}$ is positive and significant in the 
specification that does not include the SS variable and (2) in the specification that includes the SS variable, $\beta_{1}$ is positive and significant whereas $\beta_{2}$ is neither positive nor significant. Finally, by separating the CEI variable into its two basic components of CRE and CAE, we can test if there is a differential medi ating effect of SS in the connection between a firm's ethical dimension and its performance dimension. In that case, Hypothesis $3 \mathrm{~b}$ will be confirmed when, jointly with the significant coefficient of SS, the coefficient of CRE is positive, independent of whether or not the SS variable is present in the specification; however, the coefficient of CAE will only be positive when the SS variable is not included in the analysis.

\section{Results}

Table 1 reports means, standard deviations, and correlations among the main variables used in the study. Descriptive statistics show the existence of large differences between the means and medians, especially for the MVA and firm size variables. These data suggest the existence of outliers, an extreme confirmed by using the method of Hadi (1992, 1993). Thus, the implementation of robust regres sion techniques to test specifications (1) and (2) turns out to be particularly desirable.

Concerning the correlation matrix, we find that CEI and SS are positively correlated offering pre liminary support to Hypothesis 1a. Comparing the correlation coefficient between CAE and SS with the one between CRE and SS, we find that the former is larger and significant at 1\% (compared to the $5 \%$ in the case of CRE). This provides initial support for the differential effect stated in Hypothesis 1b. Furthermore, as predicted in Hypothesis 2, SS and CFP are positively correlated. However, this is not true when we use ROA as a measure of financial performance. Finally, CEI and its two basic com ponents, CRE and CAE, are positively related with the market based measure of CFP.

Table 2 summarizes the regression analysis of specification (1), whereby we test the effect of a firm's CEI on SS (Model 1A). Also, we break CEI into the two basic components: CRE and CAE (Model 2A). Finally, we study the existence of a possible complementarity between CRE and CAE.
To do so, in Model 3A we force CRE dummy variable to be " 1 " when $\mathrm{CRE}=1$ and $\mathrm{CAE}=0$ and " 0 " otherwise.

Model 1A shows that the coefficient for CEI is positive and highly significant $(\alpha=2.182, p<0.01)$ for explaining SS. These results provide strong support for Hypothesis 1a. Furthermore, when we break CEI into its two basic components (Model $2 \mathrm{~A})$, we find that both are positive and highly sig nificant $(p<0.01)$. However, CAE $(\alpha=1.107$, $p<0.01)$ contributes more than CRE $(\alpha=0.852$, $p<0.01)$ to the SS, and the difference between both is significant $(F=2.79, p>F=0.095)$. Thus, there is support for Hypothesis $1 \mathrm{~b}$. The last row of Table 2 presents the result of testing the complementarity between CRE and CAE. We observe that CRE does not affect SS whenever CAE is " 0 ". Hence, SS requires the firm to implement some tangible mea sures (e.g., defining a CAE policy) - not merely to make ethical statements (CRE).

Finally, Table 2 illustrates that the control variable for measuring R\&D investment is positive, although not significant. As expected, marketing controversies and risk are negatively and significantly related to SS and size has a positive and significant effect on SS.

Table 3 displays the regression analysis results for specification (2).

Model 1B tests the direct effect of SS on CFP. Results indicate that the effect of SS on financial performance is positive and significant $(\alpha=0.053$, $p<0.01$ ), providing support for Hypothesis 2 .

In order to test the mediating role of SS in the relationship between CEI and CFP, as mentioned, we compare Model 2B with Model 3B (Baron and Kenny, 1986). We find that CEI, initially significant in Model 2B ( $\alpha=0.296, p<0.05)$, turns out to be nonsignificant once the SS variable is introduced $(\alpha=0.186, p>0.1)$. Moreover, this latter variable is also significant $(\alpha=0.050, p<0.05)$, suggesting that it fully mediates the connection between CEI and CFP and confirming Hypothesis $3 \mathrm{a}$.

Next, Models 4B and 5B test the differential mediating effect of SS in the connection among the various components of ethical identity and CFP. We find that a differential effect exists. The significant coefficient of SS in Model 5B is accompanied by (1) a change in the coefficient of CAE from significant $(\alpha=0.145, p<0.05$; Model 4B) to nonsignificant $(\alpha=0.087, p>0.1$; Model 5B) and (2) a maintaining 


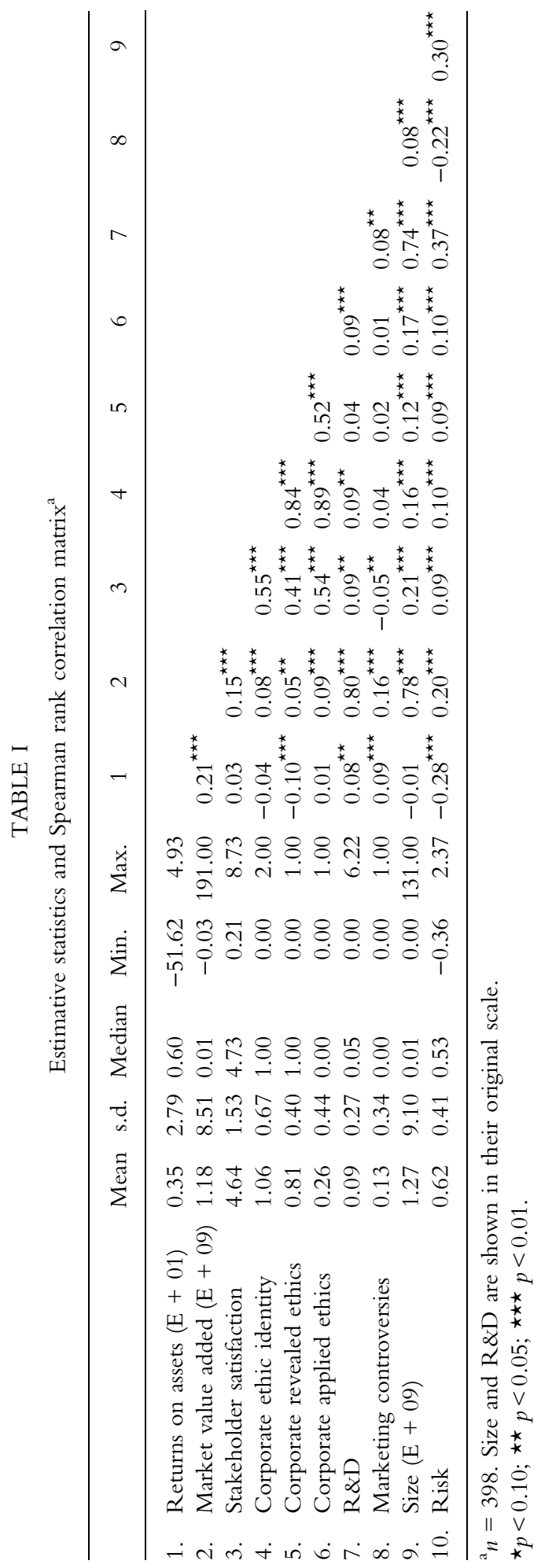

of the significance of the CRE coefficient, albeit lower in Model 5B $(\alpha=0.156, p<0.1)$ than in Model 4B $(\alpha=0.201, p<0.05)$. Hence, we can state that SS fully mediates the connection between CAE and CFP but this is not found in the rela tionship between CRE and CFP, thereby confirm ing Hypothesis $3 \mathrm{~b}$.

Finally, in the same manner used in Table 2 for SS, we test if a complementary relationship exists between CRE and CAE in their connection with CFP. To test this notion of complementarity, we use the aforementioned dummy variable for CRE that is equal to " 1 " when CRE $=1$ and $\mathrm{CAE}=0$; and " 0 " otherwise. It is remarkable that all firms in our sample using ethical programs $(\mathrm{CAE}=1)$ revealed their ethical posture in their corporate statements $(\mathrm{CRE}=1)$. However, some firms disclose their ethical posture $(\mathrm{CRE}=1)$ but do not conduct ethical programs $(\mathrm{CAE}=0)$. Model $6 \mathrm{~B}$ shows that the effect of CRE on financial performance is neg ligible when firms do not institute ethical initiatives (i.e. CAE = 0). Thus, revealing ethical information does not improve financial performance per se. Applied ethical actions are needed in order to take full advantage of ethical disclosure.

Concerning control variables, we find that $R \& D$ investment and marketing controversies have a positive and significant impact on CFP $(p<0.01$ in all models). The positive effect on CFP of marketing controversies suggests that the aforementioned effect of market power more than compensates for the negative influence of controversies through a reduction in SS. Overall, these results are consistent with those of McWilliams and Siegel (2000). Finally, in accordance with Hillman and Keim (2001), we find that size has a significant effect on CFP, while the effect of risk can be neglected.

For robustness, we replicate the previous analysis, but making use of ROA rather than MVA as a proxy of CFP. The results are consistent with Hypothesis 2 $(\alpha=0.036, p<0.1)$ and SS leads to improvements in accounting measures of CFP. However, there is no connection between the ethical stances of a firm and its accounting measure of financial performance. We relate this result to the difficulties of using accounting variables to capture the future effects on performance of the intangible resources linked to the ethical dimension of a firm. With respect to the rest of the predictor variables, we find that the marketing 
TABLE II

Results of robust regression analyses for stakeholder satisfaction ${ }^{\mathrm{a}}$

\begin{tabular}{lccc}
\hline Variable & MODEL 1A & MODEL 2A & MODEL 3A $^{c}$ \\
\hline $\begin{array}{l}\text { Corporate ethic identity } \\
\text { Corporate revealed ethics }\end{array}$ & $2.182^{\star \star \star}$ & & -0.497 \\
$\quad$ Corporate applied ethics & & $1.107 \star \star \star$ b & \\
Controls & & & 0.676 \\
R\&D & 0.462 & 0.445 & $-0.624 \star \star$ \\
Marketing controversies & $-0.750 \star \star \star$ & $-0.722 \star \star \star$ & $0.354 \star \star \star$ \\
Size & $0.194 \star \star \star$ & $0.193 \star \star \star$ & $-0.626 \star \star \star$ \\
Risk & $-0.499 \star \star \star$ & $-0.491 \star \star \star$ & Yes \\
Sector dummies & Yes & Yes & Yes \\
Country dummies & Yes & 0.594 & -1.196 \\
Constant & -0.217 & 0.441 & 0.350 \\
$R^{2}$ & 0.442 & $8.99 \star \star \star$ & $6.35 \star \star \star$ \\
$F$ Test & $9.36 \star \star \star$ & 398 & 398 \\
$N$ & 398 & &
\end{tabular}

${ }^{\mathrm{a}}$ Unstandardized regression coefficients are shown in the table.

${ }^{\mathrm{b}}$ The test of equality of coefficients showed that the marginal effect of applied ethics is significantly higher than that of revealed ethics $\left(\begin{array}{lll}F & 2.79 ; p>F & 0.095\end{array}\right)$.

${ }^{c}$ In this specification, we force corporate revealed ethics (CRE) dummy variable to be equal to 1 when CRE 1 and corporate applied ethics (CAE) 0; otherwise this dummy is 0 .

${ }^{\star} p<0.10 ;{ }^{\star \star} p<0.05 ;{ }^{\star \star \star} p<0.01$.

controversies variable has no significantly positive effect on ROA and that R\&D investment is signif icantly related to ROA in two of the five regression analyses and only at 10\% level. The negative and significant effects of size and risk on ROA are in accordance with the evidence reported by Waddock and Graves (1997) (Table 4).

\section{Discussion and conclusion}

In this paper we have introduced, as a way to approach the ethical dimensions of a firm's corporate identity, the concept of a firm's CEI as well as its two basic components of CRE and CAE. We further investigated the connections among these ethical stances and a firm's CFP, and the role of SS in mediating this relationship. As predicted, this study showed that a strong CEI was positively related to high levels of SS, which, in turn, had a positive influence on the financial performance of a firm. Hence, we conclude that the relationship between CEI and CFP is mediated by SS. Moreover, we found that each dimension of CEI (CRE and CAE) has a distinctive effect on both SS and CFP. On the one hand, CAE has a greater influence on SS than does CRE. This finding suggests that stakeholders obtain greater value from tangible ethical actions than they do from simple ethical revelation. On the other hand, we found that CRE has a positive informational effect on shareholders' value after controlling for SS, whereas CAE has no further impact on stock market value. This means that SS mediates the relationship between CAE and CFP but does not mediate the connection between CRE and CFP. Nevertheless, both ethical concepts are closely related, as we have found that ethical dis closures (CRE) only affect CFP when the disclosure is accompanied by a positive CAE. This suggests a complementary role between the two dimensions of CEI.

In addition, by using alternative measures of financial performance, we have been able to capture the intangible nature of the CEI dimension. Accounting measures of performance are recognized as having difficulties in capturing the long term 
TABLE III

Results of robust regression analyses for financial performance: market value added ${ }^{\mathrm{a}}$

\begin{tabular}{|c|c|c|c|c|c|c|}
\hline Variable & MODEL 1B & MODEL 2B & MODEL 3B & MODEL 4B & MODEL 5B & MODEL $6 \mathrm{~B}^{\mathrm{b}}$ \\
\hline Stakeholder satisfaction & $0.053 \star \star \star$ & & $0.050 \star \star$ & & $0.048 \star \star$ & $0.051 \star \star \star$ \\
\hline $\begin{array}{l}\text { Corporate ethic identity } \\
\text { Corporate revealed ethics } \\
\text { Corporate applied ethics }\end{array}$ & & $0.296 \star \star$ & 0.186 & $\begin{array}{l}0.201 \star \star \\
0.145^{\star \star}\end{array}$ & $\begin{array}{l}0.156^{\star} \\
0.087\end{array}$ & 0.207 \\
\hline \multicolumn{7}{|l|}{ Controls } \\
\hline $\mathrm{R} \& \mathrm{D}$ & $1.524 \star \star \star$ & $2.284 \star \star \star$ & $2.015 \star \star \star$ & $2.240 \star \star \star$ & $1.820 \star \star \star$ & $1.443 \star \star \star$ \\
\hline Marketing controversies & $0.347 \star \star \star$ & $0.429 \star \star \star$ & $0.428 \star \star \star$ & $0.450 \star \star \star$ & $0.430 \star \star \star$ & $0.344 \star \star \star$ \\
\hline Size & $0.191 \star \star \star$ & $0.214 \star \star \star$ & $0.200 \star \star \star$ & $0.204 \star \star \star$ & $0.187 \star \star \star$ & $0.179 \star \star \star$ \\
\hline Risk & -0.001 & -0.017 & 0.017 & -0.005 & 0.023 & 0.003 \\
\hline Sector dummies & Yes & Yes & Yes & Yes & Yes & Yes \\
\hline Country dummies & Yes & Yes & Yes & Yes & Yes & Yes \\
\hline Constant & $-2.495 \star \star \star$ & $-2.729 \star \star \star$ & $-2.822 \star \star \star$ & $-2.560 \star \star \star$ & -2.492 & $-2.319 \star \star \star$ \\
\hline$R^{2}$ & 0.720 & 0.719 & 0.731 & 0.720 & 0.718 & 0.682 \\
\hline$F$ Test & $30.61^{\star \star \star}$ & $30.08 \star \star \star$ & 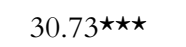 & $29.05 \star \star \star$ & $27.91 \star \star \star$ & $26.44^{\star \star \star}$ \\
\hline$N$ & 398 & 398 & 398 & 398 & 398 & 398 \\
\hline
\end{tabular}

${ }^{\mathrm{a}}$ Unstandardized regression coefficients are shown in the table.

${ }^{\mathrm{b}}$ In this specification, we force corporate revealed ethics (CRE) dummy variable to be equal to 1 when CRE 1 and corporate applied ethics (CAE) 0 ; otherwise this dummy is 0 .

${ }^{\star} p<0.10 ;{ }^{\star \star} p<0.05 ; \star \star \star ~ p<0.01$.

value of intangible resources, such as reputation, corporate culture, or knowledge assets. This diffi culty explains the null effect of the ethical dimen sions on performance in the case in which we measure performance with an accounting measure like the ROA, thereby confirming the relevance of intangible resources on a firm's CEI. Furthermore, when we focus on traditional measures of intangible investments, like R\&D investments, the relationship between intangibles and firm's ROA is weak. However, when we operationalize financial perfor mance by means of market based measures such as the MVA, a clear positive connection is found between financial performance and ethics and between financial performance and R\&D. Note that market based measures of performance are more suitable in capturing the long term value created by these intangibles: they approximate the stock mar ket's estimation of the net present value of the future stream of income generated by intangible resources.

These results have clear implications for man agement researchers and practitioners, as they com bine theoretical aspects with other aspects that have a clear practical content.

\section{Implications for research}

This paper contributes to the business ethics literature by introducing constructs aimed at capturing a firm's business ethical identity and assessing the pattern among these constructs, SS, and financial perfor mance. Theoretically, we link the relationship among these concepts and test them empirically, enhancing the limited evidence for a link between business ethics and performance. Our results indicate that a strong ethical identity can have both intrinsic and strategic value. In this regard, there have been controversies about the application of ethics as a strategic tool. For instance, Queen and Jones (1999) argued that ethical initiatives justified on a strategic basis are, in fact, unethical. Furthermore, they suggest that because an ethical stance is difficult to fake when its underlying motivation is profit maximization, such a strategy is unlikely to provide economic benefits. Hillman and Keim (2001) have also argued that participation in social and ethical issues may adversely affect the firm's ability to create shareholder wealth. However, our results show that a well built CEI has direct and indirect positive influences on financial performance. 
TABLE IV

Results of robust regression analyses for financial performance: return on assets ${ }^{\mathrm{a}}$

\begin{tabular}{|c|c|c|c|c|c|}
\hline Variable & MODEL 1C & MODEL 2C & MODEL 3C & MODEL 4C & MODEL 5C \\
\hline Stakeholder satisfaction & $0.036^{\star}$ & & $0.036^{\star}$ & & $0.036^{\star}$ \\
\hline Corporate ethic identity & & 0.067 & -0.010 & & \\
\hline Corporate revealed ethic & & & & 0.052 & 0.024 \\
\hline Corporate applied ethic & & & & 0.036 & -0.003 \\
\hline \multicolumn{6}{|l|}{ Controls } \\
\hline $\mathrm{R} \& \mathrm{D}$ & 0.533 & $0.883^{\star}$ & 0.542 & $0.817^{\star}$ & 0.495 \\
\hline Marketing controversies & 0.135 & 0.126 & 0.136 & 0.128 & 0.139 \\
\hline Size & $-0.038^{\star \star}$ & $-0.032^{\star}$ & $-0.038^{\star}$ & $-0.032^{\star}$ & $-0.038 \star \star$ \\
\hline Risk & $-0.432 \star \star \star$ & $-0.451 \star \star \star$ & $-0.434 \star \star \star$ & $-0.451 \star \star \star$ & $-0.432 \star \star \star$ \\
\hline Sector' dummies & Yes & Yes & Yes & Yes & Yes \\
\hline Country's dummies & Yes & Yes & Yes & Yes & Yes \\
\hline Constant & $2.674 \star \star \star$ & $1.737 \star \star \star$ & $1.721 \star \star \star$ & $1.775 \star \star \star$ & $1.738 \star \star \star$ \\
\hline$R^{2}$ & 0.368 & 0.353 & 0.367 & 0.355 & 0.369 \\
\hline$F$ Test & $6.88 \star \star \star$ & $6.45^{\star \star \star}$ & $6.61 \star \star \star$ & $6.29 \star \star \star$ & $6.44 \star \star \star$ \\
\hline$N$ & 398 & 398 & 398 & 398 & 398 \\
\hline
\end{tabular}

${ }^{\mathrm{a}}$ Unstandardized regression coefficients are shown in the table.

$\star p<0.10 ; \star \star x<0.05 ; \star \star \star p<0.01$.

We take advantage in this paper of the integrative line of research of stakeholder theory by combining the normative and the instrumental approaches to develop our theoretical framework. Overall, we have found support for our theoretical contentions, reinforcing the validity of the integrative approach to stakeholder theory (Gibson, 2000; Jones, 1995; Jones and Wicks, 1999). This approach appears to be a promising theoretical framework for combining ethics and business, and it is our hope that future research can refine this concept and extend the search for connecting elements.

\section{Implications for practice}

Consistent with the findings of previous studies (Berman et al., 1999; Hillman and Keim, 2001), we found that firms satisfying stakeholder demands have higher economic benefits and achieve differentiation from their competitors. Developing close relation ships with key stakeholders creates intangible re sources that are the basis for a sustainable competitive advantage. Hence, managers should recognize the importance of these relationships and place them on their strategic agenda.
From a perspective of maximizing shareholder value, previous research has depicted the importance of social disclosure on the firm's value. At the same time, some studies have shown that investing in ethical and social initiatives can, in some cases, be against the shareholders' best interests (Hillman and Keim, 2001). Our study validates the relevance of ethical disclosure practices, as investors may be able to internalize the expected future benefits through their investment decisions in financial markets. Therefore, revealing ethical values and beliefs in accordance to those of the stakeholders appears to be an adequate strategy for managers to follow.

Our study also demonstrates that although ethical initiatives do not necessarily represent profitable investments (i.e. there is not a direct influence), they do form a key determinant of SS, and that SS, in turn, boosts financial performance. Thus, ethical actions have an indirect effect on financial perfor mance through SS.

Finally, given the complementarity between CRE and CAE, we have demonstrated that firms that adopt an ethical disclosure policy disconnected from their actions may hinder their value. A company that merely adopts ethical behaviour in a symbolic manner (Stevens et al., 2005) decoupled from its 
actions runs the risk of jeopardizing its own future. And ethical disclosure, it appears, is not enough: the positive influence of ethical behaviour existed in our study only when ethical revelation was substantively coupled with ethical activities. Our research sug gests, in fact, that the effective management of eth ical identity implies a balance between ethical communications and ethical behaviours.

\section{Limitations and future research}

Although we used a unique database with a number of strengths, including its international content, we must recognize some weakness in our empirical applica tion. One such limitation is the cross sectional regression analyses on which our findings are based. Future work should attempt to expand the sample to include more years, allowing the employment of temporal lags in estimations - particularly in those estimations that include that are based on accounting measures of financial performance. Furthermore, richer panel data would allow the examination of more dynamic aspects on the connection between ethics, SS, and performance.

A second limitation is related to the way we have measured some of the variables. Consistent with previous studies, for example, we have adopted the SiRi score, which has been validated as one of the best available (Sharfman, 1996), as a measure of SS. However, the use of an index of aggregated satisfac tion precludes the analysis for particular stakeholders. It is reasonable to expect that CEI will affect SS dif ferently and that some stakeholders will have a more decisive effect on CFP than others will. Moreover, the scope of our research did not take into account the possibility that firms and managers may perceive the saliency of stakeholders differently (Mitchell et al. 1997) and their importance may have differential implications for corporate identity (Stuart, 2002). Nonetheless, we believe that our work have initial ized efforts to understand the multifaceted relations between corporate identity, ethics and firm perfor mance. A more fine grained theoretical and empirical analysis will be the subject of future research.

\section{Final remark}

Ethics and business are not unrelated worlds. Our work provides strong support for the position that ethical behaviour is ultimately in the company's best financial interest. It also demonstrates the strength of ethical behaviour in creating positive social conse quences by providing greater satisfaction to stake holders. It seems clear, then, that the effective management of CEI can play a significant role in the overall performance of the firm.

\section{Acknowledgements}

The authors wish to thank Carlos Bendito, Eva Ramos and Ramón Pueyo (Fundación Ecología y Desarrollo), Philippe Spicher (Sustainable Investment Research International, SiRi Company), and Analistas Internacio nales en Sostenibilidad (AIS ${ }^{\mathrm{TM}}$ ) a SiRi Company partner firm based in Spain for their helpful com ments and access to the SiRi Pro ${ }^{\mathrm{TM}}$ database. We also acknowledge the financial support of the Ministerio de Ciencia y Tecnologia (Grant \#SEC 200303797 and \#SEC2001 0445), and SEJ 200601731 and Comunidad de Madrid y Universidad Carlos III (Grant\#UC317 ECO 05 04Z) Ministerio de Educación y Ciencia (Grant \#SEJ 200407877 C02 02).

\section{Notes}

1 There are other features that influence the corpo rate identity of firms: for example, the competitive environment in which the company interacts, the per sonality of the original owners, the behaviours of employees, and the products and services it offers. The focus of our paper, however, is exclusively on the relationship between the firm and its stakeholders. We thank an anonymous reviewer for this clarifying sug gestion.

2 The distribution of firms by country is as follows: $30.49 \%$ US, $17.28 \%$ UK, $12.23 \%$ Swiss, 6.6\% French, 6.02\% Japanese, 5.63\% German, 4.08\% Dutch, 3.3\% Italian, 2.72\% Swedish, 1.94\% of Spanish, 1.36\% Bel gian, 1.36\% Finnish, 1.17\% Hong Kong, 0.97\% Cana dian, $0.97 \%$ Danish, $0.78 \%$ Irish, 0.58\% Australian, $0.58 \%$ Korean, $0.39 \%$ Norwegian, $0.39 \%$ Portuguese, and one firm each from Austria, China, Luxemburg, Taiwan, Thailand, and Singapore.

3 Although the debate of who is the stakeholder and to whom the firm should turn its attention is still an open one (Mitchell et al., 1997, Jensen, 2001, Hill and Jones, 1992), it seems that there is more agreement on the topic of which stakeholders are primary to the firm. 
These primary stakeholders are those whose participa tion is essential for the firm's survival (Clarkson, 1995): typically, shareholders, employees, suppliers, customers, the community, and the environment. Our aggregated measure captures all major stakeholder groups and is consistent with measures used in previous research (e.g., Hillman and Keim, 2001).

4 Corporate governance is a proxy of shareholder sat isfaction, as it assumes higher values when: (a) The positions of Chairman and CEO are not combined; (b) There is a maximum of $20 \%$ of executive directors on the board; (c) There is no limitation of shareholders rights; (d) the company has one class of stock or the company's classes of stock have equal voting rights; and (e) There is an independent audit, remuneration, and nomination committee.

5 We thank one of the referees for this suggestion.

\section{References}

Agle, B. R., R. K. Mitchell and J. A. Sonnenfeld: 1999, 'Who Matters to Managers? An Investigation of Stakeholder Attributes and Salience, Corporate Per formance, and Manager Values', Academy of Manage ment Journal 42(5), 507525.

Balmer, J. M. T.: 1998, 'Corporate Identity and the Advent of Corporate Marketing', Journal of Marketing Management 14, 963996.

Balmer, J. M. T.: 2001, 'Corporate Identity, Corporate Branding and Corporate Marketing Seeing Through the Fog', European Journal of Marketing 35(3/4), 248291.

Balmer, J. M. T. and E. R. Gray: 2000, 'Corporate Identity and Corporate Communications: Creating a Competitive Advantage', Industrial and Commercial Training 32(7), 256.

Balmer, J. M. T. and E. R. Gray: 2003, 'Corporate Brands: What are they? What of them?', European Journal of Marketing 37(7/8), 972997.

Baron, R. and D. Kenny: 1986, 'The Moderator Medi ator Variable Distinction in Social Psychologicalre search: Conceptual, Strategic and Statistical Considerations', Journal of Personality and Social Psy chology 51, 173182.

Berk, R. A.: 1990, 'A Primer on Robust Regression', in J. Fox and J. S. Long (eds.Methods of Data Analysis (Sage Publications, Newburry Park, CA), pp. 292324.

Berman, S. L., A. C. Wicks, S. Kotha and T. M. Jones: 1999, 'Does Stakeholder Orientation Matter? The Relationship Between Stakeholder Management Models and Firm Financial Performance', Academy of Management Journal 42(5), 488506.
Carroll, A. B.: 1979, 'A Three Dimensional Conceptual Model of Corporate Performance', Academy of Man agement Review 4(4), 497505.

Clarkson, M. B. E.: 1995, 'A Stakeholder Framework for Analyzing and Evaluating Corporate Social Perfor mance', Academy of Management Review 20(1), 92117.

Cragg, W.: 2002, 'Business Ethics and Stakeholder The ory', Business Ethics Quarterly 12(2), 113142.

Das, T. K.: 2005, 'How Strong are The Ethical Prefer ences of Senior Business Executives?', Journal of Busi ness Ethics 56(1), 6980.

Deephouse, D. L.: 2000, 'Media Reputation as a Strategic Resource: An Integration of Mass Communication and Resource Based Theories', Journal of Management 26(6), 10911112.

Donaldson, T: 1999, 'Making Stakeholder Theory Whole', Academy of Management Review 24(2), 237241

Donaldson, T.: 2003, 'Editor's Comments: Taking Ethics Seriously A Mission Now More Possible', Academy of Management Review 28(3), 363366.

Donaldson, T. and T. W. Dunfee: 1994, 'Toward a Unified Conception of Business Ethics: Integrative Social Contracts Theory', Academy of Management Re view 19(2), 252284.

Donaldson, T. and L. E. Preston: 1995, 'The Stakeholder Theory of the Corporation: Concepts, Evidence, and Implications', Academy of Management Review 20(1), 6591.

Evan, W. and E. R. Freeman: 1983, 'A Stakeholder Theory of the Modern Corporation: Kantian Capi talism', in T. Beauchamp and N. Bowie (eds.), Ethical Theory in Business (Prentice Hall, Englewood Cliffs, NJ), pp. 7593.

Ferrell, O. C., J. Fraedrich and L. Ferrell: 2000, Business Ethics (Houghton Mifflin, Boston).

Fisher, J.: 2004, 'Social Responsibility and Ethics: Clari fying the Concepts', Journal of Business Ethics 52(4), 391400.

Fombrun, C. J.: 1996, Reputation: Realising Value From the Corporate Image (Harvard Business School Press, Bos ton, Massachusetts).

Fombrun, C. J. and C. Foss: 2004, 'Business Ethics: Corporate Responses to Scandal', Corporate Reputation Review 7(3), 284288.

Fombrun, C. J., N. A. Gardberg and M. L. Barnett: 2000, 'Opportunity Platforms and Safety Nets: Corporate Citizenship and Reputational Risk', Business and Soci ety Review 105(1), 85106.

Fombrun, C. J. and M. Shanley: 1990, 'What is in a Name? Reputation Building and Corporate Strategy', Academy of Management Journal 33(2), 233256. 
Freeman, E. R.: 1984, Strategic Management: A Stakeholder Approach (Prentice Hall, Englewood Cliffs, NJ).

Freeman, E. R.: 1999, 'Divergent Stakeholder Theory', Academy of Management Review 24(2), 233236.

Freeman, E. R. and J. McVea: 2001, 'A Stakeholder Approach to Strategic Management', in M. Hitt, E. R. Freeman and J. Harrison (eds.), Handbook of Strategic Management (Blackwell Publishing, Oxford, U.K), pp. 189207.

Friedman, M.: 1970, 'The Social Responsibility of Business is to Increase its Profits', New York Times Magazine 13, 3233.

Fritz, J. M. H., R. C. Arnett and M. Conkel: 1999, 'Organizational Ethical Standards and Organizational Commitment', Journal of Business Ethics 20(4), 289299.

Garriga, E. and D. Melé: 2004, 'Corporate Social Responsibility Theories: Mapping the Territory', Journal of Business Ethics 53(1 2), 5171.

Gibson, K.: 2000, 'The Moral Basis of Stakeholder Theory', Journal of Business Ethics 26(3), 245257.

Gray, E. R. and J. M. T. Balmer: 1998, 'Managing Corporate Image and Corporate Reputation', Long Range Planning 31(5), 695702.

Grojean, M. W., C. J. Resick, M. W. Dickson and D. B. Smith: 2004, 'Leaders, Values, and Organizational Climate: Examining Leadership Strategies for Estab lishing an Organizational Climate Regarding Ethics', Journal of Business Ethics 55(3), 223241.

Hadi, A. S.: 1992, 'Identifying Multiple Outliers in Multivariate Data', Journal of the Royal Statistical Society 54(3), 761771.

Hadi, A. S.: 1993, 'A Modification of a Method for the Detection of Outliers in Multivariate Samples', Journal of the Royal Statistical Society 56(2), 393396.

Hamilton, L.: 1992, Regression with Graphics: A Second Course in Applied Statistics (Duxbury Press, California).

Harrison, J. and E. R. Freeman: 1999, 'Stakeholders, Social Responsibility, and Performance: Empirical Evidence and Theoretical Perspectives', Academy of Management Journal 42(5), 479485.

Hatch, M. J. and M. Schultz: 1997, 'Relations Between Organizational Culture, Identity and Image', European Journal of Marketing 31(5), 356365.

Healy, P. M. and K. G. Palepu: 2001, 'Information Asymmetry, Corporate Disclosure, and the Capital Markets: A Review of the Empirical Disclosure Literature', Journal of Accounting and Economics 31(1), 405440.

Hill, C. and T. M. Jones: 1992, 'Stakeholder Agency Theory', Journal of Management Studies 29(2), 131154.

Hillman, A. J. and G. D. Keim: 2001, 'Shareholder Value, Stakeholder Management, and Social Issues: What's the Bottom Line?', Strategic Management Journal 22, 125139.
Hosmer, L. T.: 1994, 'Strategic Planning as of Ethics Mattered', Strategic Management Journal 15(Special Is sue), 1734 .

Hummels, H. and D. Timme: 2004, 'Investors in Need of Social, Ethical, and Environmental Information', Jour nal of Business Ethics 52(1), 7384.

Jensen, M. C.: 2001, 'Value Maximization, Stakeholder Theory, and the Corporate Objective Function', Journal of Applied Corporate Finance 14(3), 821.

Jones, T. M.: 1995, 'Instrumental Stakeholder Theory: A Synthesis of Ethics and Economics', Academy of Man agement Review 20(2), 404437.

Jones, T. M. and A. C. Wicks: 1999, 'Convergent Stakeholder Theory', Academy of Management Review 24(2), 206221.

Leuthesser, L. and C. Kohli: 1997, 'Corporate Identity: The Role of Mission Statements', Business Horizons 40(3), 5666.

Logsdon, J. M. and K. Yuthas: 1997, 'Corporate Social Performance, Stakeholder Orientation, and Organi zational Moral Development', Journal of Business Ethics 16, 12131226.

Lorraine, N. H., D. J. Collison and D. M. Power: 2004, 'An Analysis of the Stock Market Impact of Environ mental Performance Information', Accounting Forum 28(1), 727.

Margolis, J. D. and J. P. Walsh: 2003, 'Misery Loves Companies: Rethinking Social Initiatives by Business', Administrative Science Quarterly 48(2), 268304.

Markwick, N. and C. Fill: 1997, 'Towards a Framework for Managing Corporate Identity', European Journal of Marketing 31(5/6), 396409.

McWilliams, A. and D. Siegel: 2000, 'Corporate Social Responsibility and Financial Performance: Correlation or Misspecification?', Strategic Management Journal 21(5), 603609.

Melewar, T. C. and E. Jenkins: 2002, 'Defining the Corporate Identity Construct', Corporate Reputation Review 5(1), 7690.

Mitchell, R. K., B. R. Agle and D. J. Wood: 1997, 'Toward a Theory of Stakeholder Identification and Salience: Defining the Principle of Who and What Really Counts', Academy of Management Review 22(4), 853886.

Moskowitz, M: 1975, 'Profiles in Corporate Responsi bility: The Ten Worst, The Ten Best', Business and Society Review 13, 842.

Orlitzky, M., F. L. Schmidt and S. L. Rynes: 2003, 'Corporate Social and Financial Performance: A Meta Analysis', Organization Studies 24(3), 403441.

Pfeffer, J. and G. R. Salancik: 1978, The External Control of Organizations: A Resource Dependence Perspective (Harrper \& Row, New York). 
Philips, R. A.: 1997, 'Stakeholder Theory and the Prin ciple of Fairness', Business Ethics Quarterly 7, 51-66.

Phillips, R. A. and J. Reichart: 2000, 'The Environment as a Stakeholder? A Fairness Based Approach', Journal of Business Ethics 23(2), 185-197.

Ponemon, L. and C. Michaelson: 2000, 'Ethics at the Core', Perspectives Pricewaterhouse Coopers 2, 4-9.

Post, J. E., L. E. Preston and S. Sachs: 2002, 'Managing the Extended Enterprise: The New Stakeholder View', California Management Review 45(1), 6-28.

Rawwas, M. Y. A., Z. Swaidan and M. Oyman: 2005, 'Consumer Ethics: A Cross Cultural Study of the Ethical Beliefs of Turkish and American Consumers', Journal of Business Ethics 57(2), 183-195.

Roberts, P. W. and G. R. Dowling: 2002, 'Corporate Reputation and Sustained Superior Financial Perfor mance', Strategic Management Journal 23, 1077-1093.

Roberts, R.: 1992, 'Determinants of Corporate Social Responsibility Disclosure', Accounting, Organizations and Society 17(6), 595-612.

Rockness, H. and J. Rockness: 2005, 'Legislated Ethics: From Enron to Sarbanes Oxley, the Impact on Cor porate America', Journal of Business Ethics 57(1), 31-54.

Schwab, B.: 1996, 'A Note on Ethics and Strategy: Do Good Ethics Always Make for Good Business?', Stra tegic Management Journal 17, 499-500.

Scott, S. G. and V. R. Lane: 2000, 'A Stakeholder Approach to Organizational Identity', Academy of Management Review 25(1), 43-62.

Sethi, S. P.: 2005, 'Investing in Socially Responsible Companies is a Must for Public Pension Funds - Be cause there is No Better Alternative', Journal of Business Ethics 56(2), 99-129.

Sharfman, M.: 1996, 'The Construct Validity of the Kinder, Lydenberg \& Domini Social Performance Rating Data', Journal of Business Ethics 15, 287-296.

Stevens, J. M., H. K. Steensma, D. A. Harrison and P. L. Cochran: 2005, 'Symbolic or Substantive Document? The Influence of Ethics Codes on Financial Executives' Decisions', Strategic Management Journal 26, 181-195.

Strong, K. C., R. C. Ringer and S. A. Taylor: 2001, 'The Ruled of Stakeholder Satisfaction (Timeliness, Honesty, Empathy)', Journal of Business Ethics 32(3), 219-230.

Stuart, H.: 2002, 'Employee Identification with the Corporate Identity', International Studies of Management E Organization 32(3), 28-44.
Tannous, G.: 1997, 'Capital Budgeting for Advertising Expenditures: A Contingent Claims Approach', Review of Quantitative Finance and Accounting 8, 109-128.

Treviño, L. K. and G. R. Weaver: 1999, 'The Stake holder Research Tradition: Convergent Theorists Not Convergent Theory', Academy of Management Review 24(2), 222-227.

van Rekom, J.: 1997, 'Deriving an Operational Measure of Corporate Identity', European Journal of Marketing 31(5/6), 410.

van Riel, C. B. M.: 1995, Principles of Corporate Commu nication (Prentice Hall, New York).

van Riel, C. B. M. and J. M. T. Balmer: 1997, 'Cor porate Identity: The Concept, Its Measurement and Management', European Journal of Marketing 31(5/6), 340-355.

Waddock, S. A. and S. B. Graves: 1997, 'The Corporate Social Performance Financial Performance Link', Strategic Management Journal 18(4), 303-319.

Walsh, J. P., K. Webber and J. D. Margolis: 2003, 'Social Issues and Management: Our Lost Cause Found', Journal of Management 29(6), 859-881.

Wartick, S. L. and P. L. Cochran: 1985, 'The Evaluation of the Corporate Social Performance Model', Academy of Management Review 10(4), 758-769.

Weaver, G. R., L. K. Treviño and P. L. Cochran: 1999, 'Integrated and Decoupled Corporate Social Perfor mance: Management Commitments, External Pres sures, and Corporate Ethics Practices', Academy of Management Journal 42(5), 539-552.

Wicks, A. C., D. R. Gilbert, Jr. and E. R. Freeman: 1994, 'A Feminist Reinterpretation of the Stakeholder Concept', Business Ethics Quarterly 4, 475-498.

Wood, D. J.: 1991, 'Corporate Social Performance Revisited', Academy of Management Review 16(4), 691-718.

Pascual Berrone, Jordi Surroca and Josep A. Tribó Department of Business Administration, Universidad Carlos III de Madrid, Calle Madrid 126, 28903, Getafe, Madrid, Spain E-mail: pascual.berrone@uc3m.es 